\title{
Desorption of Copper from Some New Zealand Soils
}

\author{
Desma S. Hogg, Ronald G. McLaren, ${ }^{*}$ and Roger S. Swift
}

\begin{abstract}
Availability of soil $\mathrm{Cu}$ to plants is dependent on the desorption into the soil solution of $\mathrm{Cu}$ from the surfaces of soil colloidal materials. Although there have been many studies of $\mathrm{Cu}$ sorption by soils, however, few have examined the process of $\mathrm{Cu}$ desorption. The objective of this study was to examine some of the factors likely to affect the desorption from soils of both native $\mathrm{Cu}$ and $\mathrm{Cu}$ added to soils. Ten New Zealand soils were used in this study and $\mathrm{Cu}$ desorption was determined by repeated equilibrations in $0.01 \mathrm{M} \mathrm{Ca}\left(\mathrm{NO}_{3}\right)_{2}$ solution. Desorption of native soil $\mathrm{Cu}$ varied between soils and the proportion of the total labile $\mathrm{Cu}$ in the soil (as determined by EDTA [ethylenediamine tetraacetic acid] extraction) that could be desorbed readily was strongly influenced by pH. Below pH 6.5, desorption increased with decreasing $\mathrm{pH}$, and above $\mathrm{pH} 6.5$ increased with increasing $\mathrm{pH}$. When $\mathrm{Cu}$ was added to the soils $\left(7 \mathrm{mg} \mathrm{Cu} \mathrm{kg}{ }^{-1}\right.$ soil) with an initial contact period between added $\mathrm{Cu}$ and soil of $24 \mathrm{~h},<8.5 \%$ of the added $\mathrm{Cu}$ could be desorbed readily. The proportion of added $\mathrm{Cu}$ desorbed was reduced substantially by increasing the contact period to $12 \mathrm{wk}$ before desorption. Desorption of native soil $\mathrm{Cu}$ was increased by increasing the temperature at which desorption was carried out. The effect of temperature on the desorption of added $\mathrm{Cu}$ differed between soils. The results of this study provide more evidence for the existence of slow reactions between added $\mathrm{Cu}$ and soil that reduce the ability of the $\mathrm{Cu}$ to desorb back into the soil solution.
\end{abstract}

$I^{\mathrm{T}}$ IS NOW generally accepted that soil solution concentrations of micronutrients (and hence availability to plants) are probably controlled by sorptiondesorption reactions at the surfaces of soil colloidal materials (Swift and McLaren, 1991). However, although numerous studies have examined the sorption of $\mathrm{Cu}$ by soils and soil components (McLaren and Crawford, 1973; Jarvis, 1981; McLaren et al., 1981; Raikhy and Takkar, 1981; Sanders, 1982), very few studies have examined the reverse process, i.e., desorption of $\mathrm{Cu}$ into solution. As noted by Swift and McLaren (1991), this is in some ways a paradox, since it is desorption processes that are likely to control the amount and rate of release of $\mathrm{Cu}$ (or other micronutrients) into solution for plant uptake. Of the few $\mathrm{Cu}$ desorption studies reported in the literature, most have examined desorption from individual soil components, e.g., McLaren et al., 1983; Padmanabham, 1983a. An exception to this is the study reported by Lehmann and Harter (1984), who examined the desorption kinetics of $\mathrm{Cu}$ applied to an intact soil. However our understanding of the factors affecting desorption of $\mathrm{Cu}$ from soils is far from complete. Such information is required in order to improve our ability to predict the release of both native $\mathrm{Cu}$ from soils and the release of $\mathrm{Cu}$ added to soils as a fertilizer or as a pollutant.

The objective of our study was to examine the de-

D.S. Hogg, Woodward-Clyde Consultants, 1550 Hotel Circle North, San Diego, CA 92108; R.G. McLaren, Dep. of Soil Science, Lincoln Univ., Canterbury, New Zealand; and R.S. Swift, Dep. of Soil Science, Univ. of Reading, London Road, Reading, England. Received 20 Apr. 1992. *Corresponding author.

Published in Soil Sci. Soc. Am. J. 57:361-366 (1993). sorption of both native and applied $\mathrm{Cu}$ from a range of New Zealand soils. In particular, the effects of soil $\mathrm{pH}$ and temperature on $\mathrm{Cu}$ desorption were studied and, in the case of applied $\mathrm{Cu}$, the effect of contact time between the $\mathrm{Cu}$ and the soil.

\section{MATERIALS AND METHODS}

\section{Soils}

Samples of topsoil $(0-250 \mathrm{~mm})$ were collected from 10 sites in New Zealand representing a wide range of soil types. The soils were selected to give a range in soil properties that were considered likely to influence the desorption behavior of soil $\mathrm{Cu}$, e.g., organic matter, $\mathrm{pH}$, clay, and $\mathrm{Fe}$ and $\mathrm{Al}$ oxide contents. The samples were air dried and ground to pass a $2-\mathrm{mm}$ stainless steel sieve before use. The soils and some selected properties are listed in Table 1 . The analyses shown in this table were carried out using the methods of Blakemore et al. (1987).

\section{Desorption of Native Soil Copper}

Desorption of $\mathrm{Cu}$ from soils was determined by repeatedly equilibrating samples of soil $(5.0 \mathrm{~g}$ in duplicate) with $0.01 \mathrm{M}$ $\mathrm{Ca}\left(\mathrm{NO}_{3}\right)_{2}(35 \mathrm{~mL})$. Equilibrations were carried out for $2 \mathrm{~h}$ in polypropylene tubes on an end-over-end shaker at $20^{\circ} \mathrm{C}$. Preliminary studies indicated that there was little change in the amount of $\mathrm{Cu}$ desorbed from soil after the first $2 \mathrm{~h}$ of equilibration. After each 2-h equilibration period, the samples were centrifuged, and the supernatant solution decanted and filtered through a $5.0-\mu \mathrm{m}$ membrane filter. The soil was resuspended in fresh $0.01 M \mathrm{Ca}\left(\mathrm{NO}_{3}\right)_{2}$ and the procedure repeated as necessary. The pHs of the desorption solutions were determined at the end of each 2-h desorption period and, for all soils, $\mathrm{pH}$ remained fairly constant during successive desorptions. These $\mathrm{pH}$ values, averaged for 10 desorption periods $\left(\mathrm{pH}_{\mathrm{DES}}\right)$, were generally within 0.2 to $0.3 \mathrm{pH}$ units of the soil $\mathrm{pH}$ values shown in Table 1.

Total $\mathrm{Cu}$ concentrations in the solutions were determined by atomic absorption spectrophotometry, using electrothermal atomization. Cumulative $\mathrm{Cu}$ desorption was calculated from the $\mathrm{Cu}$ concentrations in successive equilibration solutions.

\section{Desorption of Added Copper}

Samples of Lismore, Taupo, Temuka, and Waiareka soils (5.0 $\mathrm{g}$ in duplicate) were equilibrated at $20^{\circ} \mathrm{C}$ for $24 \mathrm{~h}$ with $35 \mathrm{~mL} 0.01 M \mathrm{Ca}\left(\mathrm{NO}_{3}\right)_{2}$ containing $1.0 \mu \mathrm{g} \mathrm{Cu} \mathrm{mL}^{-1}$ (equivalent to $7.0 \mathrm{mg} \mathrm{Cu} \mathrm{kg} \mathrm{kg}^{-1}$ soil). The concentration of $\mathrm{Cu}$ remaining in solution after $24 \mathrm{~h}$ was determined as described above and the $\mathrm{Cu}$ sorbed by the soil calculated by difference from the initial concentration. After decanting the original solution, the soils were resuspended in fresh $\mathrm{Ca}\left(\mathrm{NO}_{3}\right)_{2}$ and $\mathrm{Cu}$ desorption determined as described above.

\section{Effect of Contact Time between Soil and Added Copper on Subsequent Desorption}

For the Lismore and Temuka soils, in addition to an initial contact time of $24 \mathrm{~h}$ (as above), the experiment was repeated using contact times of $2 \mathrm{~h}, 4 \mathrm{wk}, 8 \mathrm{wk}$, and $12 \mathrm{wk}$. Microbial activity was inhibited in the 4-, 8-, and 12-wk samples using $1 \mathrm{~mL}$ of $0.002 \%$ chlorhexidine.

For comparative purposes, samples of Lismore and Temuka soils without added $\mathrm{Cu}$ were also equilibrated with $\mathrm{Ca}\left(\mathrm{NO}_{3}\right)_{2}$ 
Table 1. Selected properties of soils used in desorption studies.

\begin{tabular}{|c|c|c|c|c|c|c|c|}
\hline Soil series & $\begin{array}{l}\text { New Zealand } \\
\text { soil group }\end{array}$ & $\begin{array}{l}\text { U.S. soil } \\
\text { taxonomy }\end{array}$ & $\underset{\left(\mathrm{H}_{2} \mathrm{O}\right)}{\mathrm{pH}}$ & $\underset{\mathrm{C}}{\text { Organic }}$ & $\begin{array}{c}\text { Oxalate } \\
\text { Fe }\end{array}$ & $\begin{array}{c}\text { Oxalate } \\
\mathrm{Al}\end{array}$ & Clay \\
\hline & & & & $\mathrm{g} \mathrm{kg}^{-1}$ & $\mathrm{~g} \mathrm{~kg}^{-1}$ & $\mathrm{~g} \mathrm{~kg}^{-1}$ & $\mathrm{~g} \mathrm{~kg}^{-1}$ \\
\hline $\begin{array}{l}\text { Craigiebum } \\
\text { Lismore } \\
\text { Takahe } \\
\text { Taupo } \\
\text { Te Anau } \\
\text { Templeton } \\
\text { Temuka } \\
\text { Wajareka } \\
\text { Waikari } \\
\text { Waikuku }\end{array}$ & $\begin{array}{l}\text { Yellow-Brown Earth } \\
\text { Yellow-Brown Stony Soil } \\
\text { Yellow-Grey Earth } \\
\text { Yellow-Brown Pumice Soil } \\
\text { Yellow-Brown Loam } \\
\text { Recent/Yellow-Grey Earth } \\
\text { Gley } \\
\text { Brown Granular Loam } \\
\text { Rendzina } \\
\text { Yellow-Brown Sand }\end{array}$ & $\begin{array}{l}\text { Typic Dystrochrept } \\
\text { Umbric Dystrochrept } \\
\text { Typic Fragiochrept } \\
\text { Typic Vitrandept } \\
\text { Typic Haplumbrept } \\
\text { Udic Ustrochrept } \\
\text { Typic Haplaquept } \\
\text { Typic Hapludoll } \\
\text { Udic Haplustoll } \\
\text { Typic Ustipsamment }\end{array}$ & $\begin{array}{l}5.0 \\
5.1 \\
5.3 \\
5.0 \\
5.4 \\
5.8 \\
5.6 \\
6.5 \\
7.6 \\
4.6\end{array}$ & $\begin{array}{l}52 \\
36 \\
28 \\
82 \\
79 \\
41 \\
59 \\
78 \\
57 \\
22\end{array}$ & $\begin{array}{r}7 \\
3 \\
4 \\
4 \\
13 \\
5 \\
4 \\
11 \\
3 \\
1\end{array}$ & $\begin{array}{r}6 \\
3 \\
2 \\
12 \\
16 \\
3 \\
4 \\
10 \\
5 \\
1\end{array}$ & $\begin{array}{l}350 \\
260 \\
270 \\
200 \\
220 \\
250 \\
420 \\
410 \\
360 \\
110\end{array}$ \\
\hline
\end{tabular}

for the above periods of time before $\mathrm{Cu}$ desorption was determined.

\section{Effect of Temperature on Desorption}

The desorption procedure described above for native soil $\mathrm{Cu}$ was repeated for the Lismore and Temuka soils using equilibration temperatures of 10 and $30^{\circ} \mathrm{C}$. These temperatures were also used to study desorption of added $\mathrm{Cu}\left(7 \mathrm{mg} \mathrm{Cu} \mathrm{kg}{ }^{-1}\right.$ soil) from these two soils after an initial contact time of $24 \mathrm{~h}$ at $20{ }^{\circ} \mathrm{C}$.

\section{Extractable Soil Copper}

Samples of soil $(5.0 \mathrm{~g}$ in duplicate) were shaken with 35 $\mathrm{mL}$ of $0.04 M$ EDTA on an end-over-end shaker at $20^{\circ} \mathrm{C}$ for $24 \mathrm{~h}$. The samples were centrifuged before the supernatant solution was filtered through a Whatman no. 41 filter paper.

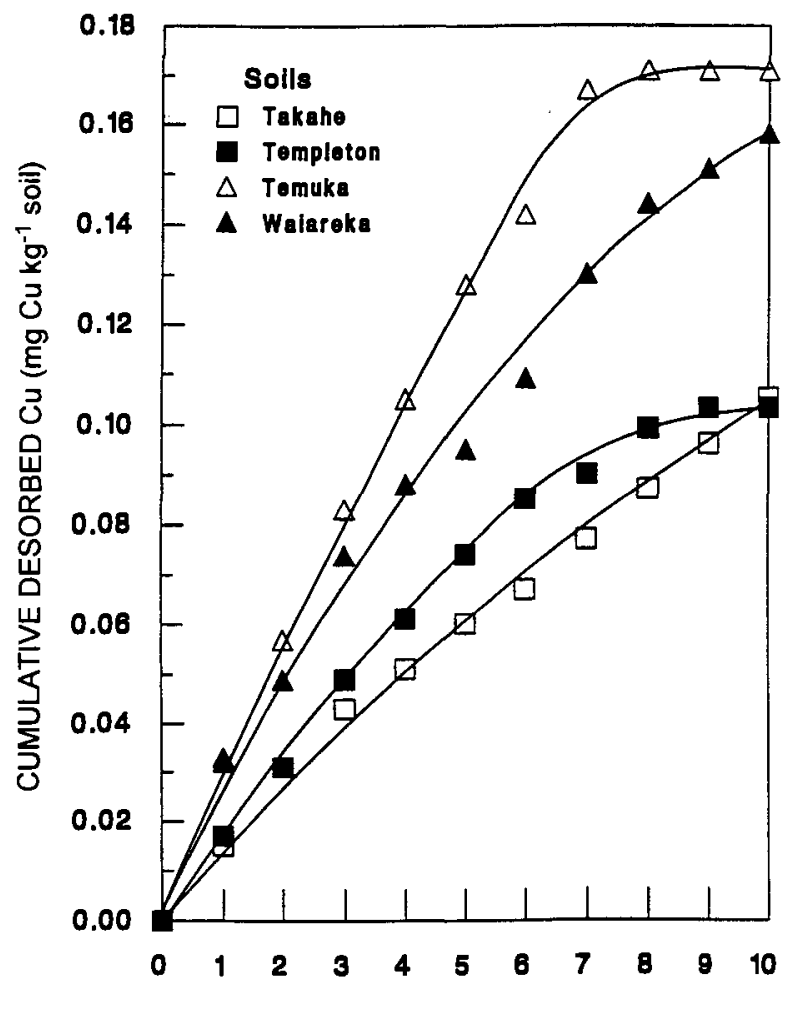

NUMBER OF DESORPTION PERIODS

Fig. 1. Cumulative desorption of native soil $\mathrm{Cu}$ from some New Zealand soils.
Copper was determined in the filtrate by flame atomic absorption spectrophotometry.

\section{RESULTS AND DISCUSSION Desorption of Native Soil Copper}

Figure 1 shows the cumulative amounts of native soil $\mathrm{Cu}$ desorbed from four of the experimental soils during 10 successive 2 -h desorption periods. The amounts and patterns of desorption differed between the soils. The cumulative amount of native $\mathrm{Cu}$ desorbed ranged from $0.087 \mathrm{mg} \mathrm{Cu} \mathrm{kg}^{-1}$ for the Waikari soil up to $0.171 \mathrm{mg}$ $\mathrm{Cu} \mathrm{kg}{ }^{-1}$ for the Temuka soil (Table 2). For six of the experimental soils (Lismore, Taupo, Te Anau, Templeton, Temuka, and Waikari), the amounts of $\mathrm{Cu}$ desorbed were highest in the initial few periods and reached a plateau after six or seven desorption periods. The remaining four soils (Craigieburn, Takahe, Waiareka, and Waikuku), however, were still releasing measurable amounts of $\mathrm{Cu}$ at the completion of 10 desorption periods. These four soils appear to have a much more sustainable ability to release C.u into solution than the other soils examined.

It is interesting to compare the cumulative amounts of $\mathrm{Cu}$ desorbed after 10 equilibrations with $\mathrm{Ca}\left(\mathrm{NO}_{3}\right)_{2}$, with the amounts of $\mathrm{Cu}$ extracted from the same soils with EDTA. This reagent is widely used to estimate plantavailable $\mathrm{Cu}$ in soils (Sims and Johnson, 1991), and may be considered an estimate of total labile soil $\mathrm{Cu}$. In Table 2 , the cumulative amount of $\mathrm{Cu}$ desorbed is expressed as a percentage of EDTA-extractable $\mathrm{Cu}$ for each of the soils. Except for the Waikuku soil, less than the equivalent of $30 \%$ of EDTA-extractable Cu could be desorbed

Table 2. Cumulative desorbed native soil $\mathrm{Cu}$ and ethylene diaminetetraacetic acid (EDTA)-extractable Cu concentrations.

\begin{tabular}{lccc}
\hline Soil & $\begin{array}{c}\text { Cumulative } \\
\text { desorbed Cu } \dagger\end{array}$ & $\begin{array}{c}\text { EDTA-extractable } \\
\text { Cu }\end{array}$ & $\begin{array}{c}\text { Desorbed Cu as } \\
\text { EDTA-Cu }\end{array}$ \\
\hline Craigieburn & $\mathrm{mg} \mathrm{kg}^{-1}$ soil & $\mathrm{mg} \mathrm{kg}^{-1}$ soil & $\%$ \\
Lismore & 0.17 & 0.92 & 18.3 \\
Takahe & 0.09 & 0.35 & 26.6 \\
Taupo & 0.11 & 0.82 & 12.8 \\
Te Anau & 0.12 & 0.83 & 14.9 \\
Templeton & 0.09 & 0.53 & 17.2 \\
Temuka & 0.10 & 2.71 & 3.8 \\
Waiareka & 0.17 & 3.69 & 4.6 \\
Waikari & 0.16 & 5.08 & 3.1 \\
Waikuku & 0.09 & 1.33 & 6.5 \\
\hline
\end{tabular}

$\uparrow 10$ desorption periods. 
after 10 desorption equilibrations with $\mathrm{Ca}\left(\mathrm{NO}_{3}\right)_{2}$. For the Templeton, Temuka, Waiareka, and Waikari soils, $<10 \%$ of the EDTA-extractable $\mathrm{Cu}$ values could be desorbed. Although EDTA is one of the extractants that has shown the most consistent success in predicting soil $\mathrm{Cu}$ availability to plants (Sims and Johnson, 1991), the comparison with the desorption data would suggest that extraction with this reagent overestimates the amount of readily plant-available $\mathrm{Cu}$ in soils. This is not surprising since EDTA extracts $\mathrm{Cu}$ predominantly from the organic fraction of the soil (McLaren and Crawford, 1973), much of which is probably not directly available to plants. In contrast, desorption of $\mathrm{Cu}$ into a dilute $\mathrm{Ca}\left(\mathrm{NO}_{3}\right)_{2}$ solution will depend not only on the total amount of labile $\mathrm{Cu}$ in the soil but also on other factors. These are likely to include the types, quantities, and relative proportions of soil components responsible for the retention of $\mathrm{Cu}$ in the soil, and the soil $\mathrm{pH}$.

Attempts were made to relate the cumulative amounts of $\mathrm{Cu}$ desorbed from the soils to the above parameters. There was no statistically significant correlation between cumulative desorbed $\mathrm{Cu}$ and EDTA-extractable $\mathrm{Cu}$ or with any of the other soil properties shown in Table 1 . However, the cumulative amount of $\mathrm{Cu}$ desorbed (10 desorptions) expressed as a percentage of EDTA-extractable $\mathrm{Cu}$ did appear to be related to $\mathrm{pH}_{\mathrm{DES}}$. This relationship was described well (significant at $P<0.005$ ) by a second-order polynomial equation that shows a decrease in desorption with increasing $\mathrm{pH}$, reaching a minimum at approximately

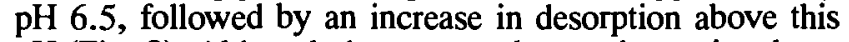
$\mathrm{pH}$ (Fig. 2). Although there was only one data point above $\mathrm{pH} 6.5$, it is considered that the fitted data trend is realistic. Copper solubility in soils has been shown to increase at both low and high $\mathrm{pH}$ values (McBride and Blasiak, 1979; Swift and McLaren, 1991).

The increase in desorption with decreasing $\mathrm{pH}$ below 6.5 is similar to the trend observed by Padmanabham (1983a), when studying the desorption of $\mathrm{Cu}$ from goethite, an Fe oxide commonly found in soils. Padmanabham (1983a) proposed the existence of specific sites in goethite, which are responsible for the irreversible (or very slowly reversible) sorption of $\mathrm{Cu}$ and showed that the proportion of such sites increased with $\mathrm{pH}$. Cavallaro and McBride (1984) have also shown that desorption of $\mathrm{Cu}$ from soil clays decreases with an increase in $\mathrm{pH}$.

The fact that desorption of $\mathrm{Cu}$ from the soil labile $\mathrm{Cu}$ pool is influenced by $\mathrm{pH}$ clearly has implications for the uptake of soil $\mathrm{Cu}$ by plants. Desorption data on its own, however, will not necessarily provide an effective measure of soil $\mathrm{Cu}$ availability. Many other factors in addition to purely physico-chemical ones are also involved, not least the plant itself and its influence on the root environment.

\section{Desorption of Added Soil Copper}

All four soils used in this part of the study sorbed virtually all (>98\%) of the added $\mathrm{Cu}\left(7 \mathrm{mg} \mathrm{Cu} \mathrm{kg} \mathrm{mg}^{-1}\right.$ soil) during the initial 24 -h equilibration period. Subsequent successive desorptions from the soils resulted in large increases in the amounts of $\mathrm{Cu}$ desorbed compared with samples where native $\mathrm{Cu}$ only was present, e.g., the Lismore and Taupo soils, Fig. 3. For all four soils, however, the proportions of added $\mathrm{Cu}$ desorbed during 10 desorption periods were extremely low, ranging from

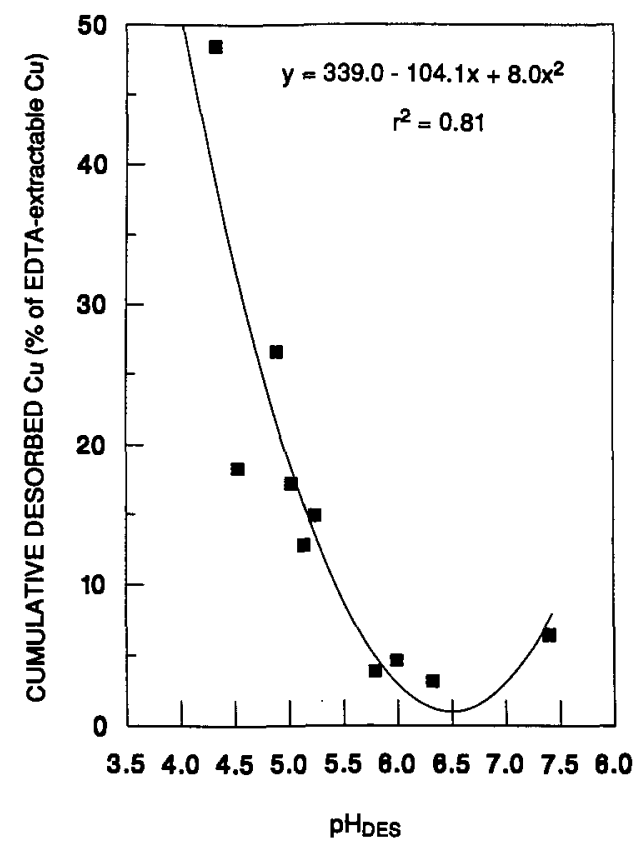

Fig. 2. Relationship between cumulative desorbed native soil Cu (10 desorption periods) and the mean $\mathrm{pH}$ of the desorption solution ( $\mathrm{pH}_{\mathrm{DES}}$ ).

$2.4 \%$ for the Waiareka soil to $8.3 \%$ for the Taupo. This relatively low desorption of added $\mathrm{Cu}$ occurred even though the initial contact period between the added $\mathrm{Cu}$ and the soil had been relatively short ( $24 \mathrm{~h})$.

The low proportions of added $\mathrm{Cu}$ desorbed from the soils agrees with the results of previous studies with individual soil components. Sorption of $\mathrm{Cu}$ by a range of soil components has been shown to be largely irreversible or only slowly reversible (McLaren et al., 1983; Padmanabham, 1983a,b; McBride et al., 1984). Various hypotheses have been put forward to explain this type of behavior. McBride (1991) stated that activation energies for desorption may be much larger than those for sorption, and rates of sorption at ambient temperature are likely to be much faster than desorption rates. Thus the low proportions of added $\mathrm{Cu}$ desorbed in this and other studies may reflect, in part, nonequilibrium conditions caused by slow desorption rather than true irreversibility. Barrow (1985) has also indicated that initial sorption reactions may be followed by slower reactions that would render a proportion to the sorbed $\mathrm{Cu}$ unavailable for immediate equilibrium with the soil solution. It is uncertain, however, whether such reactions are likely to be of importance for a relatively short sorption period of $24 \mathrm{~h}$.

Although such small proportions of the added $\mathrm{Cu}$ were desorbed during 10 desorption equilibrations, it should be noted that at the end of this period $\mathrm{Cu}$ was still being desorbed (Fig. 3). It might be expected that, with time, greater amounts of the added $\mathrm{Cu}$ could be desorbed back into solution and therefore be considered to remain available for plant uptake.

\section{Effect of Contact Time on Desorption of Added Copper}

A preliminary experiment (data not shown) was carried out that compared desorption of applied $\mathrm{Cu}$ from 
(a) LISMORE

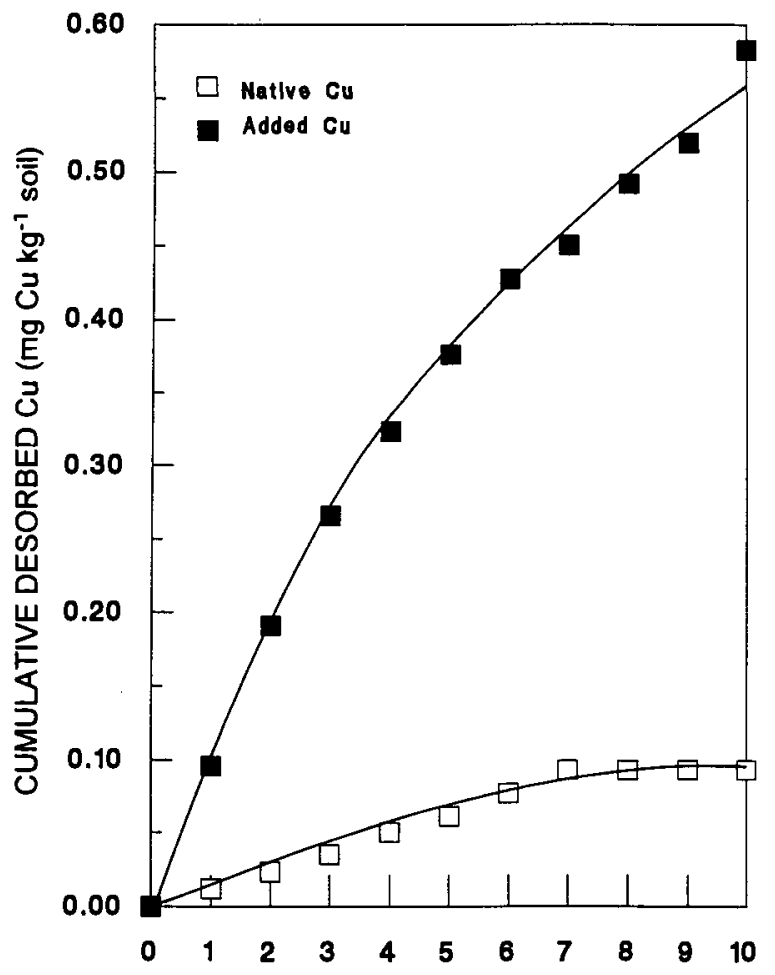

(b) TAUPO

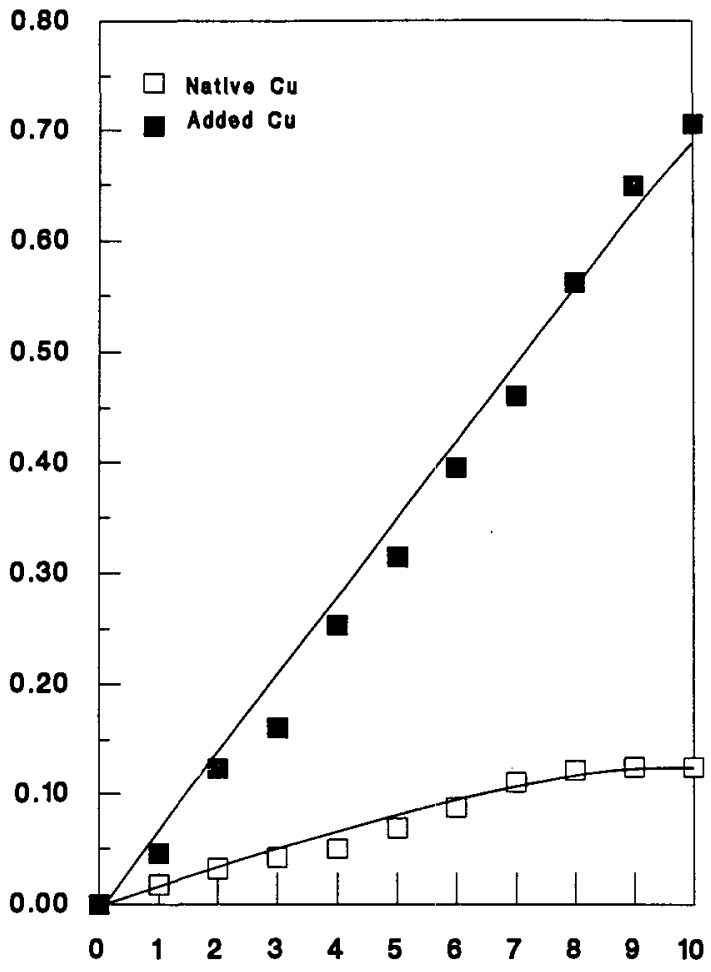

NUMBER OF DESORPTION PERIODS

Fig. 3. Cumulative desorption of native and added $\mathrm{Cu}$ from Lismore and Taupo soils (added $\mathrm{Cu}$ treatment $=7 \mathrm{mg}^{\mathrm{Cu}} \mathrm{kg}^{-1} \mathrm{soil}^{-}$)

the Waiareka soil after an initial sorption period of $2 \mathrm{~h}$, with the desorption obtained after a $24-\mathrm{h}$ sorption period. At the completion of 10 desorption periods, although the difference was not large numerically, significantly more $\mathrm{Cu}$ had been desorbed from the soil that had been in contact with the added $\mathrm{Cu}$ for the shorter period of time (3.3\% of the added Cu compared with $2.4 \%$ ).

As a result of this preliminary study, a longer term experiment was carried out with the Lismore and Temuka soils using initial contact periods of 4,8 , and 12 wk before desorption of the added $\mathrm{Cu}$ was measured. Figure 4 shows clearly that, for both soils, the amount of $\mathrm{Cu}$ desorbed declined with increasing contact time between the added $\mathrm{Cu}$ and the soil. These results are in general agreement with the trends reported for $\mathrm{Cu}$ desorption from goethite by Padmanabham (1983a) and from soil by Lehmann and Harter (1984). In both of these studies, the longer the period between the initial sorption of $\mathrm{Cu}$ and the start of desorption, the greater the amount of $\mathrm{Cu}$ that was irreversibly sorbed. The nature of the slow reactions that result in this decrease in desorption of added $\mathrm{Cu}$ remains open to conjecture. Solid diffusion into mineral lattice structures has been suggested, but McBride (1991) pointed out that such reactions would be extremely slow indeed. It would appear more likely that, with increased time of sorption, there is a slow redistribution of $\mathrm{Cu}$ ions to more strongly binding or less accessible sites, possibly involving diffusion into extremely small pores and interparticle spaces. Although the actual amounts of $\mathrm{Cu}$ involved in these slow reactions appear to be small compared with the total amounts of $\mathrm{Cu}$ sorbed, they do represent a considerable proportion of the $\mathrm{Cu}$ that can initially be desorbed from the soil. Therefore, the corresponding effects on plant availability of added $\mathrm{Cu}$ could also be significant.

For comparison purposes, samples of Lismore and Temuka soils without added $\mathrm{Cu}$ were also equilibrated in $\mathrm{Ca}\left(\mathrm{NO}_{3}\right)_{2}$ for periods of 4,8 , and 12 wk before $\mathrm{Cu}$ desorption was determined. The results of these controls are also shown in Fig. 4. Somewhat unexpectedly, native soil $\mathrm{Cu}$ also showed a decrease in desorption with increasing time of initial equilibration. It might be thought that native soil $\mathrm{Cu}$ would be in an equilibrium state and continuing reactions with soil components was unlikely. In common with other nutrients, however, $\mathrm{Cu}$ will be continually cycled in the soil through decaying organic materials and, through eventual mineralization, a pool of $\mathrm{Cu}$ ions will be maintained that has not had time to react irreversibly with the soil. Interruption of nutrient cycling (by sampling the soil) will stop the supply of $\mathrm{Cu}$ from this source and $\mathrm{Cu}$ already present in soluble or sorbed forms will gradually be subject to the slow reactions discussed above. It also seems likely, however, that the nature of the equilibration process in $\mathrm{Ca}\left(\mathrm{NO}_{3}\right)_{2}$ at a wide solution/soil ratio creates conditions favorable for the slow reactions to take place. The rates at which such reactions occur in soils at normal soil moisture contents is probably much slower than those observed in soil suspensions in the laboratory. Evidence that slow reactions between $\mathrm{Cu}$ and soil do also occur in field-moist soils has been obtained by Williams and McLaren (1982). These workers showed that during a period of $44 \mathrm{wk}$, EDTA extractability of both native and added $\mathrm{Cu}$ declined in soils incubated under field-moist conditions. 


\section{(a) LISMORE}

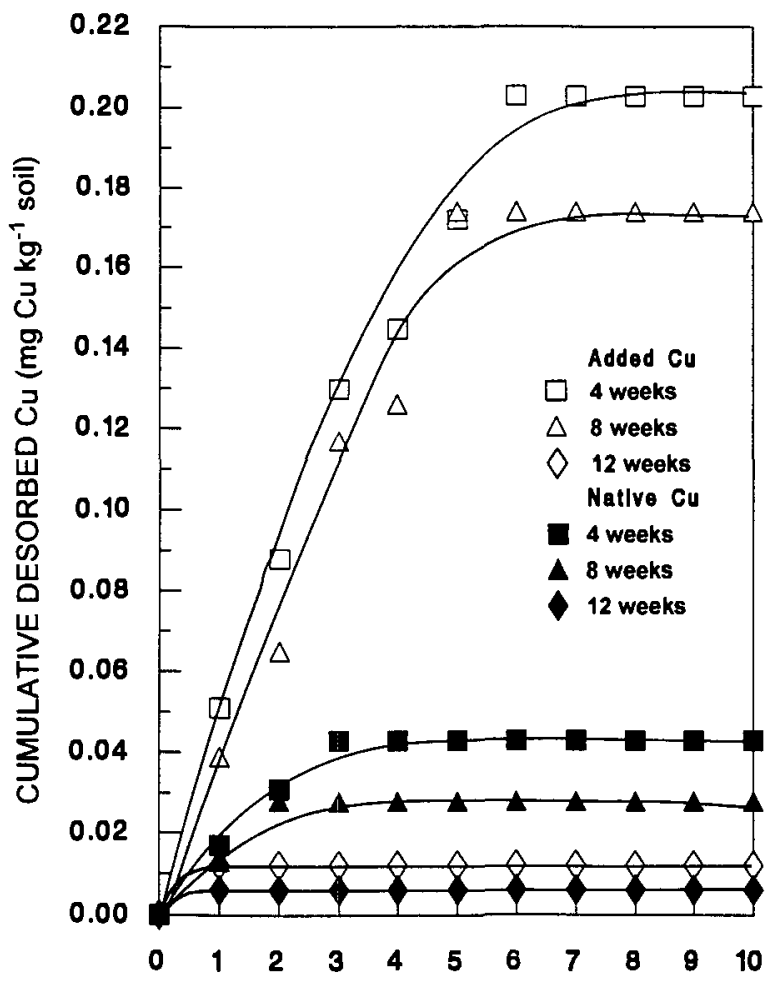

(b) TEMUKA

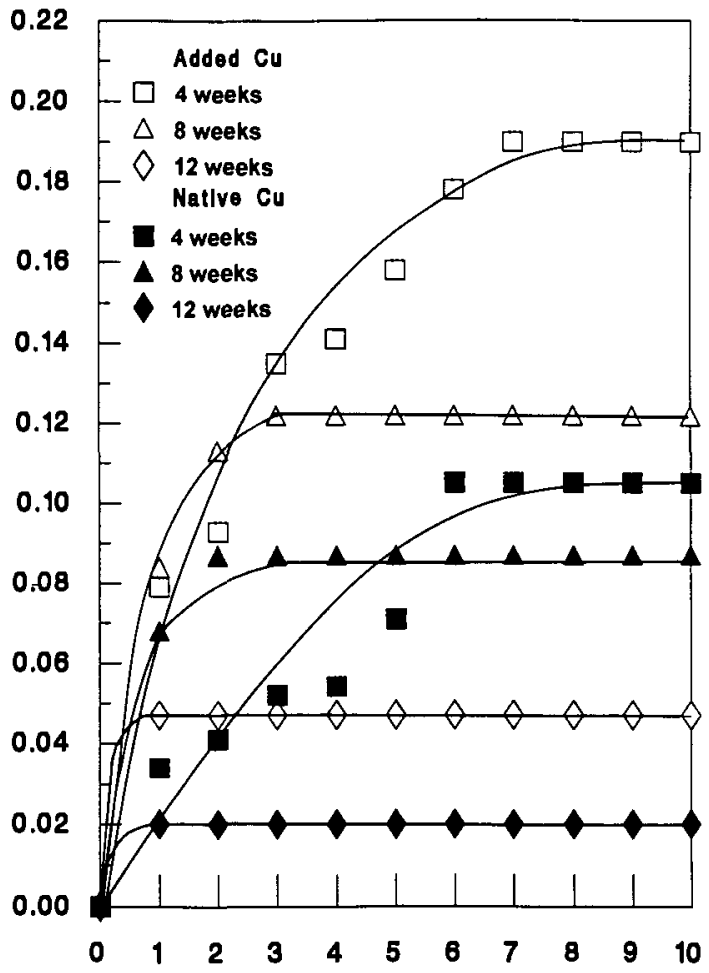

\section{NUMBER OF DESORPTION PERIODS}

Fig. 4. Cumulative desorption of native and added $\mathrm{Cu}$ from Lismore and Temuka soils following initial equilibration periods of different lengths.

Fox (1992), in field experiments with a range of soils, has also shown a decrease with time in the extractability of $\mathrm{Cu}$ applied as a fertilizer.

\section{Effect of Temperature on Copper Desorption}

For both the Lismore and Temuka soils, the amount of native soil $\mathrm{Cu}$ desorbed (11 desorption periods) increased with increasing temperature of equilibration (Fig. 5). Such an effect would be expected if, as stated by McBride (1991), desorption requires a significant activation energy.

The effect of increasing temperature of equilibration on the desorption of added $\mathrm{Cu}$ differed between the two soils. With the Lismore soil, the cumulative amount of added $\mathrm{Cu}$ desorbed decreased with increasing temperature (Fig. 5), i.e., the reverse of what occurred with native soil $\mathrm{Cu}$. With the Temuka soil, there was little difference between the amounts of $\mathrm{Cu}$ desorbed at the three equilibration temperatures.

The results for added $\mathrm{Cu}$ can be explained by considering the effect of temperature not just on the desorption process itself, but also on the slow reactions that gradually decrease the ability of added $\mathrm{Cu}$ to desorb back into solution. In view of the results described above, it is likely that these slow reactions would have been continuing during the time taken to carry out the desorption equilibrations. The rate of these reactions, particularly if diffusion processes are involved, would be expected to increase with an increase in temperature. Thus the over- all effect of temperature on the desorption of added $\mathrm{Cu}$ will be a net effect of temperature on desorption (desorption increasing with temperature as observed for native soil $\mathrm{Cu}$ ) and on the slow reactions ( $\mathrm{Cu}$ available for desorption decreasing with temperature). In the case of the Lismore soil it would appear that the effect of temperature on the slow reactions was the dominant effect and thus the net effect was a decrease in desorption with increasing temperature (Fig. 5a). With the Temuka soil the effects of temperature on the two types of process appeared to be balanced, with no marked net effect of temperature on desorption (Fig. 5b). The difference between the soils is no doubt related to differences in properties between the two soils. For example, the Temuka soil had higher organic $\mathrm{C}, \mathrm{Fe}$ and $\mathrm{Al}$ oxide, and clay contents than the Lismore soil; it also had a higher $\mathrm{pH}$ value (Table 10 ).

\section{CONCLUSIONS}

The amount of $\mathrm{Cu}$ that can desorb readily from soil depends not only on the total amount of labile $\mathrm{Cu}$ in the soil but also on soil $\mathrm{pH}$, temperature, and, in the case of added $\mathrm{Cu}$, on the length of time since addition of the $\mathrm{Cu}$ to the soil. The observations made in this study provide additional evidence for the existence of slow reactions that reduce the ability of $\mathrm{Cu}$ sorbed by soils to desorb readily back into solution. The occurrence of such reactions clearly has implications for the long-term availability to plants of $\mathrm{Cu}$ added to soils as fertilizer or as a pollutant. 
(a) LISMORE

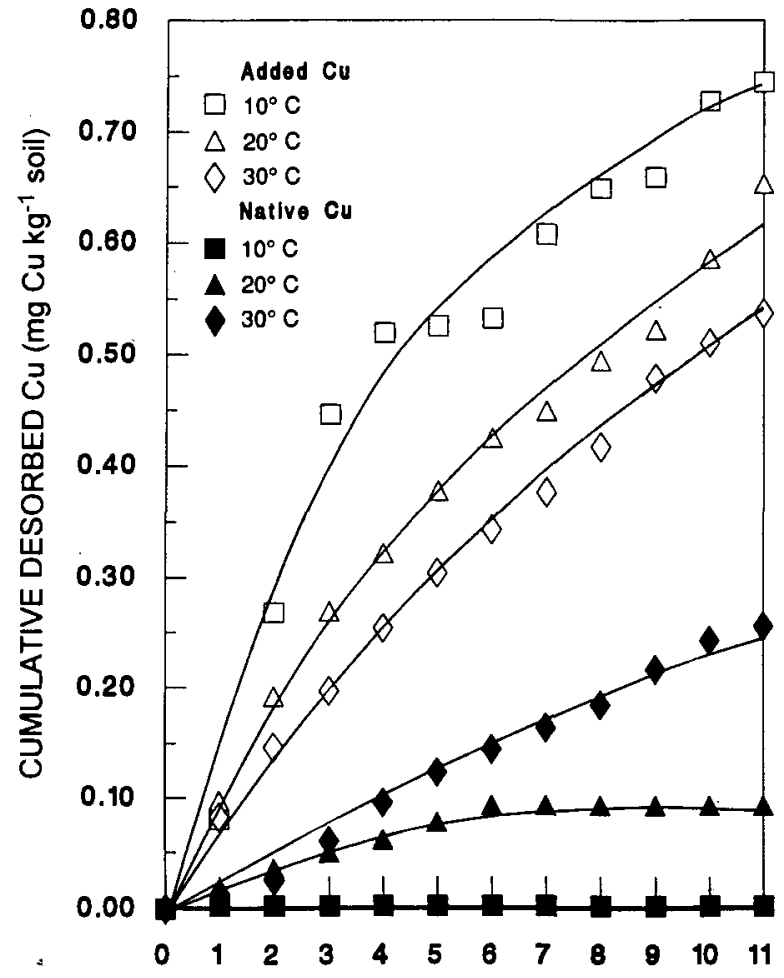

(b) TEMUKA

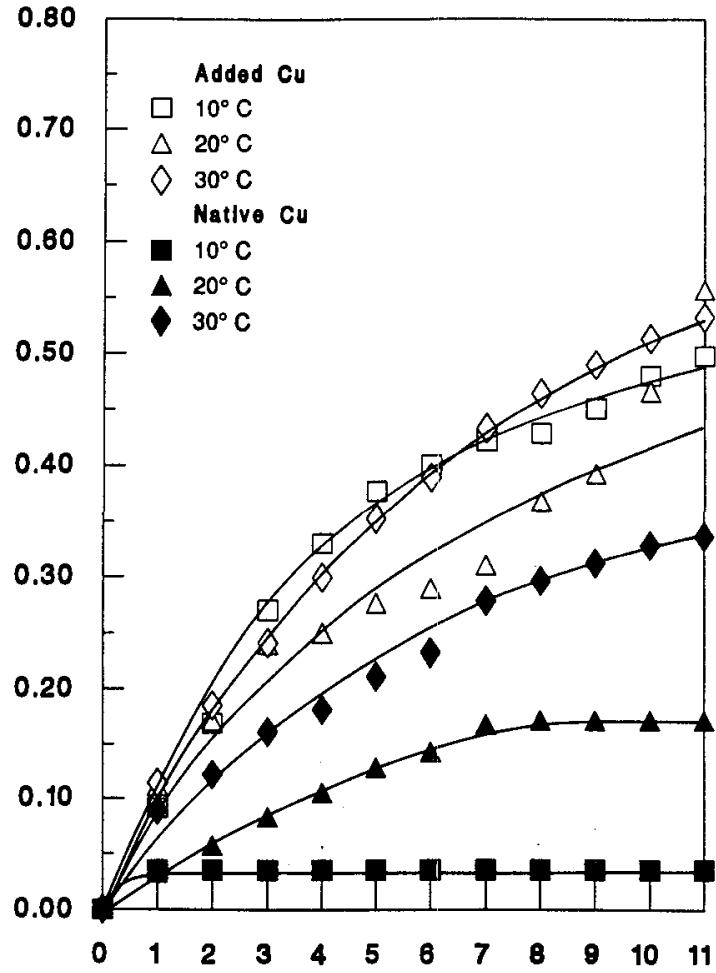

\section{NUMBER OF DESORPTION PERIODS}

Fig. 5. Cumulative desorption of native and added Cu from Lismore and Temuka soils at different temperatures.

\section{REFERENCES}

Barrow, N.J. 1985. Reactions of anions and cations with variablecharge soils. Adv. Agron. 38:183-230.

Blakemore, L.C., L.C. Searle, and B.K. Daly. 1987. Methods for chemical analysis of soils. New Zealand Soil Bureau Scientific Rep. 80. N.Z. Soil Bureau, Lower Hutt, New Zealand.

Cavallaro, N., and M.B. McBride. 1984. Zinc and copper sorption and fixation by an acid soil clay: Effect of selective dissolutions. Soil Sci. Soc. Am. J. 48:1050-1054.

Fox, F.R. 1992. Residual value of copper fertilization. Commun. Soil Sci. Plant Anal. 23:101-112.

Jarvis, S.C 1981. Copper sorption by soils at low concentrations and relation to uptake by plants. J. Soil Sci. 32:257-269.

Lehmann, R.G., and R.D. Harter. 1984. Assessment of coppersoil bond strength by desorption kinetics. Soil Sci. Soc. Am. J. 48:769-772.

McBride, M.B. 1991. Processes of heavy and transition metal sorption by soil minerals. p. 149-175. In G.H. Bolt et al. (ed.) Interactions at the soil colloid-soil solution interface. Kluwer Academic Publ.; Dordrecht, the Netherlands.

McBride, M.B., and J.J. Blasiak. 1979. Zinc and copper solubility as a function of $\mathrm{pH}$ in an acid soil. Soil Sci. Soc. Am. J.43:866-870.

McBride, M.B., A.R. Fraser, and W.J. McHardy. 1984. $\mathrm{Cu}^{2+}$ interaction with microcrystalline gibbsite. Evidence for oriented chemisorbed copper ions. Clays Clay Miner. 32:1218.

McLaren, R.G., and D.V. Crawford. 1973. Studies on soil cop- per: II. The specific sorption of copper by soils. J. Soil Sci. 24:443-452.

McLaren, R.G., J.G. Williams, and R.S. Swift. 1981. The sorption of copper by soil materials at low equilibrium solution concentrations. J. Soil Sci. 32:247-256.

McLaren, R.G., J.G. Williams and R.S. Swift. 1983. Some observations on the desorption and distribution behaviour of copper with soil components. J. Soil Sci. 34:325-331.

Padmanabham, M. 1983a. Adsorption-desorption behaviour of copper(II) at the goethite-solution interface. Aust. J. Soil Res. 21:309-320.

Padmanabham, M. 1983b. Comparative study of the adsorptiondesorption behaviour of copper(II), zinc(II), cobalt(II) and lead(II) at the goethite-solution interface. Aust. J. Soil Res. 21:515525 .

Raikhy, N.P., and P.N. Takkar. 1981. Copper sorption by soils and its relations with plant growth. Z. Pflanzenernahr. Bodenkd. 144:597-612.

Sanders, J.R. 1982. The effect of pH upon the copper and cupric ion concentrations in soil solutions. f. Soil Sci. 33:679-689.

Sims, J.T., and G.V. Johnson. 1991. Micronutrient soil tests. p. 427-476. In J.J. Mortvedt et al. (ed.) Micronutrients in agriculture. 2nd ed. SSSA, Madison, WI.

Swift, R.S., and R.G. McLaren. 1991. Micronutrient sorption by soils and soil colloids. p. 257-292. In G.H. Bolt et al. (ed.) Interactions at the soil colloid-soil solution interface. Kluwer Academic Publ., Dordrecht, the Netherlands.

Williams, J.G., and R.G. McLaren. 1982. Effects of dry and moist incubation of soils on the extractability of native and applied soil copper. Plant Soil 64:215-224. 